\title{
Leprosy in Cuba
}

\author{
DR MIGUEL A. GONZÁLEZ PRENDES \\ Hospital 'San Luis de Jagua', Ministry of Public Health, Cuba \\ (Original in Spanish, translated by Dr J. Ross Innes)
}

Cuba is a long narrow island which is situated in the sea of the Antilles between North and South America, at the entrance to the Gulf of Mexico, and sited in the torrid zone and between $19^{\circ} 48^{\prime}$ and $23^{\circ} \mathrm{I} 3^{\prime}$ of north latitude and $74^{\circ} \mathrm{o} 8^{\prime}$ and $84^{\circ} 57^{\prime}$ of longitude, west.

The lands nearest to Cuba are the United States of North America at $\mathrm{I} 80 \mathrm{~km}$., Mexico at 2 I $\mathrm{km}$., Haiti at $77 \mathrm{~km}$., and Jamaica at $140 \mathrm{~km}$. Cuba has a territorial extent of I 1 4,524 square $\mathrm{km}$. I $200 \mathrm{~km}$., long and an average breadth of I $00 \mathrm{~km}$. The present population consists of 7,390,222 inhabitants.

The nation is formed of ethnic groups of white, black, mixed, and yellow races, chiefly.

Cuba has a hot tropical climate and according to Prof. S. Massip, 'The climate is determined by the neighbourhood of the mass of North America which restrains the effect of insularity. The temperatures and the winds are influenced by the high and low temperatures and the different pressures which appear in the continent. Normally without storms there is easy passage for the winds, and the great stabilizing influence of the sea attenuates the climatic variations.

The average annual temperature of Cuba is $25^{\circ} \mathrm{C}$ and the winter average is $2 \mathrm{I}^{\circ} \mathrm{C}$ with a range of $10^{\circ} \mathrm{C}$ to $22^{\circ} \mathrm{C}$. There are exceptionally low temperatures in some regions of the island when $0^{\circ} \mathrm{C}$ has been recorded. The summer average is $27^{\circ} \mathrm{C}$, with fluctuations between $19^{\circ} \mathrm{C}$ and $36^{\circ} \mathrm{C}$, and in a very rare case $36^{\circ} \mathrm{C}$ has been reported, as at Sagua de Tánamo in Oriente province in 1927.

We have only two seasons, the dry from December to April, and the wet from May to November.

The annual average precipitation is $1.40 \mathrm{~m}$., $75 \%$ of it in the rainy season. The western region registers the most, and the south coast of
Oriente province maintains the record for dryness.

The average relative humidity is $72 \%$.

The average atmospheric pressure is $762 \mathrm{~mm}$. The maximum is in January with $764 \mathrm{~mm}$., and the minimum in October with $760 \mathrm{~mm}$.

Cuba is an independent sovereign state. Its territorial divisions are 6 departments called provinces, each subdivided into municipalities and these again into wards.

There are 2 hospitals completely dedicated to the treatment of leprosy (I) Hospital of San Lázaro in Havana Province, with 300 beds; (2) the sanatorium of San Luis de Jagua in Oriente Province, with 4 oo beds.

Properly registered and supervised there exist in Cuba 4,020 patients suffering from leprosy.

With dispensary treatment there exist 3,470 patients, and there are $55^{\circ}$ patients hospitalized.

There are io dermatological centres throughout the provinces. There is I at Pinar del Rio, 3 at Havana, I at Matanzas, I at Las Villas, I at Camagüey, and 3 in Oriente. The endemic leprosy is spread over the whole country.

Ages

Of the 4,020 patients there are $2.51 \%$ at age o to I 4 years, and $97.49 \%$ at ages of 15 years and more. Most are met with at 20 years of age and more. There is an increase of incidence from 20 years until the third decade of life is reached, when the maximum incidence is found. The curve descends slowly at 32 years.

In studies carried out at the National Sanatorium of 'San Luis de Jagua' among 2,2 I 9 patients who had passed through it since its opening in 1944 we have been able to establish that more than $65 \%$ of the patients were included between age groups 20 and 35 years. The average age is 28.5 . 
Races

The white race was $56.68 \%$, the black I $5.45 \%$, the mixed $27.33 \%$ and the yellow $0.54 \%$. The racial percentages are approximately similar to those which exist in the healthy population.

\section{Sex}

Males were $59.24 \%$ and females $40.76 \%$. These percentages are also approximately equal to those in the general population of the country, except for a slight preponderance of males in the general population.

\section{Civil state}

Unmarried were $39.48 \%$, married were $52.89 \%$, widow or widower $5.8 \mathrm{I} \%$, divorced $\mathrm{I} .82 \%$. In this it will be noted that the percentage for unmarried is less than for the married. This throws into relief the opinion of some authors who think that in the affected population a greater number of unmarried exist. They attribute this to the terror which leprosy inspires, and above all the deformities caused sometimes by leprosy. This is the chief cause of their being rejected by the opposite sex. In our opinion it is not certain. The married predominate in official records of patients, and the unmarried predominate in records of the hospitalized. The reason is obvious. The married cannot abandon the hearth and leave the wife and children unprotected. They only come to hospital when there is no other remedy. The position of the unmarried is different. In most cases they do not have home obligations, and the hospital represents a welcome relief, as well as securing them health of body. It spiritually re-animates them, and frees them from a sea of misunderstandings among which they live.

\section{Nationality}

Cubans were $95.67 \%$ and foreigners $4.53 \%$. We encountered leprosy among foreigners mostly among Spaniards, Chinese, Haitians, and Jamaicans, but these are the nucleus of those foreigners settled in Cuba.

\section{Occupations}

Farmers, wives and children

Unemployed

Housework

Clerks
Small traders

$3.53 \%$

Washerwomen

$3.32 \%$

Labourers

I. $86 \%$

Drivers, carters, and muleteers $\quad \mathrm{I} \cdot 54 \%$

We wish to point out those occupations where the incidence is over I $\%$, also to explain those called 'small traders' are really ambulant vendors or bosses of humble establishments.

\section{Clinical Forms}

The lepromatous form occurred clinically in $44.43 \%$, the tuberculoid in $24.01 \%$, the indeterminate in $19.29 \%$, the dimorphous in $0.32 \%$, the unclassified in $12.04 \%$. Patients under control were $87.30 \%$, and uncontrolled I $2.70 \%$. At the present time we have under medical control $87.30 \%$ of all our patients. The terms 'under control' or 'controlled' mean that we were able to examine the patient and give him the treatment personally at least once every 60 days. When a patient comes to the dermatological clinic, after studying and examining the case he is given the medicaments which have to be used during 2 months, af ter previously completing all necessary laboratory examinations and tests. He is advised on the regularity to be followed and summoned to a return visit at the end of a given time. If he fails to do that, then he enters a group which we call 'tardy in treatment' and his file is delivered to responsible special auxiliaries, so that he may be visited in his domicile so as to find out the cause which has made him interrupt treatment, solve the difficulties behind the delay and bring him back to active and regular control.

When a patient has too much invalidism from disease or age and cannot attend the centre he is visited in his own home, and examined and treated, with his contacts. So we do with urban patients and contacts, and so maintain control.

Those who live in rural zones are visited by leprologists in their own homes. We have thus established a regular calendar of visits and we go regularly to the rural foci every 6 months. We carry out the rural work in conjunction with the doctors of the rural medical service, who in a total of 47 function in the whole national territory. Taking as base the hospital which is sited nearest the focus, the special auxiliaries in charge of the zone visit the focus, previously calling the patients, those living with them, and contacts together to the hospital on a chosen 
date for examination by the leprologist and the general doctors resident in the hospital. Every patient is discussed with the general doctors. The necessary laboratory examinations and tests are carried out, the indicated drugs are given, and these patients continue directly under the control of the doctors of the rural hospital, to which the patient will return, to be visited by the leprologist at the end of 6 months, if not previously summoned. The patients who have not been able to attend the rural hospital are visited in their own homes, just as we do with the patients of urban zones. The mobile team which we have available for these tasks of each region consists of a jeep, a leprologist, and a special auxiliary.

\section{S U M M AR Y}

I. Leprosy is found uniformly spread through all the national territory in direct relation to the number of inhabitants in each province;

2. 3,470 patients receive outpatient treatment and $55^{\circ}$ are hospitalized;

3. Minors of 14 years of age make up $3.51 \%$ of total number of patients;

4. Lepromatous rate of the Cuban leprosy patients is $44.43 \%$;

5. We have under therapeutic control $87.30 \%$ of the total;

6. We can estimate approximately 6,ooo leprosy patients existing in Cuba.

APPENDIX

Leprosy Patients in Cuba by Provinces

\begin{tabular}{|c|c|c|c|c|c|c|c|}
\hline PROVINCE & $\begin{array}{l}\text { Area in } \\
S q . K m .\end{array}$ & Population & $\begin{array}{c}\text { Density } \\
\text { per } \\
S q . K m .\end{array}$ & $\begin{array}{c}\text { Total } \\
\text { of } \\
\text { Patients }\end{array}$ & $\begin{array}{l}\text { Prevalence } \\
\text { per I } 000 \\
\text { population }\end{array}$ & $\begin{array}{l}\text { Patienls } \\
\text { per ıоо } \\
S q . K m .\end{array}$ & $\begin{array}{l}\text { Percentage } \\
\text { of the total } \\
\text { of patients }\end{array}$ \\
\hline Pinar del Rio & I 3,500 & $5^{18,496}$ & $3^{8.4}$ & I 09 & $0.2 \mathrm{I}$ & $0.8_{\mathrm{I}}$ & $2.7 \mathrm{I}$ \\
\hline Habana & 8,221 & $2,093,597$ & 254.7 & I,097 & $0.5^{2}$ & I 3.34 & 27.29 \\
\hline Matanzas & 8,444 & 455,796 & 54.0 & ${ }^{1} 5^{8}$ & 0.35 & I. 87 & $3 \cdot 93$ \\
\hline Las Villas & 21,4 II & $\mathrm{I}, 240,359$ & 57.9 & 501 & $0.4^{0}$ & 2.34 & I 2.46 \\
\hline Camagüiey & 26,346 & 795,864 & 30.2 & 475 & 0.60 & I. 80 & I I 82 \\
\hline Oriente & 36,602 & 2,286, I I 6 & 62.4 & І ,680 & 0.74 & $4 \cdot 59$ & 41.79 \\
\hline CUBA & I 14,524 & $7,390,228$ & $64 \cdot 5$ & 4,020 & 0.54 & $3 \cdot 5^{I}$ & I 00.00 \\
\hline
\end{tabular}

